\title{
GEOSTATISTICAL MODELING OF THE TEN-DAY RAINFALL IN MATO GROSSO STATE
}

\author{
Vanessa Rakel de Moraes DIAS ${ }^{1}$ \\ Fernando da Silva SALLO2 \\ Luciana SANCHES 3 \\ Rivanildo DALLACORT ${ }^{4}$
}

\begin{abstract}
Mapping the spatial-temporal distribution of rainfall allows the analysis of tendencies and changes on local and regional scale, which is crucial for the development of environmental and agricultural projects. The objective of this paper is to adjust and choose semivariographic mathematical models to analyze the spatial variability of the 75 percentile rainfall in Mato Grosso State, covering October to March, to subsequently represent it on maps using Kriging techniques. Data from 155 weather stations in Mato Grosso $\mathrm{S}$ and around were used, with data for over ten years provided by the National Water Agency. The semivariograms were adjusted using the least squares method and chosen among spherical, exponential, and Gaussian models. The exponential model adjusted best to the experimental semivariograms using the criterion of standard deviation in reduced errors obtained from cross validation and level of dependence. The spatial variability of the rainfall was then mapped using Kriging techniques.
\end{abstract}

Key words: Spatial variability. Geostatistics. Least squares. Semivariogram.

\footnotetext{
${ }^{1}$ State University of Mato Grosso, CPEDA, Rod. MT 358, km 7, Jardim Aeroporto, 78300-000, Tangará da Serra-MT, Brazil. E-mail: vanessadias@unemat.br

${ }^{2}$ Federal University of Mato Grosso, Physics and Environmental Research Group, Av. Fernando Correa da Costa, n. 2367, Boa Esperança, 78060-900, Cuiabá-MT, Brazil. E-mail: fdss88@gmail.com

${ }^{3}$ Federal University of Mato Grosso, Department of Sanitary and Environmental Engineering, Av. Fernando Correa da Costa, n. 2367, Boa Esperança, 78060-900, Cuiabá-MT, Brazil. E-mail: Isanches@hotmail.com

${ }^{4}$ State University of Mato Grosso, Department of Agronomy, CPEDA, Rod. MT 358, km 7, Jardim Aeroporto, 78300-000, Tangará da Serra-MT, Brazil, E-mail: rivanildo@unemat.br
} 


\section{Resumo}

\section{Modelagem geoestatística da precipitação pluvial decendial no estado de Mato Grosso}

O mapeamento da distribuição espaço-temporal da precipitação pluvial possibilita a análise de tendências e alterações em escalas locais e regionais, imprescindíveis no desenvolvimento de projetos ambientais e agrícolas. Assim, o objetivo do presente trabalho foi ajustar e selecionar modelos matemáticos semivariográficos para a análise da variabilidade espacial dos percentis 75 da precipitação pluvial no estado de Mato Grosso, referente aos meses de outubro a março para, posteriormente, representá-la por meio de mapas por técnicas de krigagem. Dados de 155 estações pluviométricas no estado de Mato Grosso e no entorno, com dados acima de 10 anos, da Agência Nacional de Águas foram utilizados. Os semivariogramas foram ajustados pelo método dos mínimos quadrados e selecionados entre os modelos esférico, exponencial e gaussiano. O modelo que melhor se ajustou aos semivariogramas experimentais pelo critério do desvio padrão dos erros reduzidos obtido pela validação cruzada e grau de dependência espacial foi o exponencial. Assim, a variabilidade espacial da precipitação pluvial foi mapeada por técnicas de krigagem.

Palavras-chave: Variabilidade espacial. Geoestatistica. Mínimos quadrados. Semivariograma.

\section{INTRODUCTION}

Among the climatic variables, rainfall is of key importance and should be monitored for environmental planning, agricultural projects, civil construction, and civil defense, among others. To characterize regional rainfall patterns, arithmetical averages and averages determined by the Thiessen method, whether they are daily, monthly, seasonal, or annual, are not always sufficient for its application in agriculture because there are fluctuations in monthly and annual totals, as well as variations from one location to another.

Therefore, for agricultural planning, expected or probable precipitation values associated with a level of probability are used. The 75 percentile of rainfall mapped using interpolators can provide more reliable information which serves as a basis for agricultural planning. The spatial representation of the phenomenon in terms of frequency or probabilities is important because it provides information on rainfall in locations where there are no weather stations (GOMES et al., 2002).

Marcuzo et al.,(2011a) studied the total rainfall on Mato Grosso State, analyzing the spatial, temporal, and seasonal variation with data from 75 weather stations from 1977 to 2006 and created isohyetal maps using the Topo to Raster Interpolation method.

In an analysis of rainfall in the Central West portion of Mato Grosso State, covering 17 municipalities between 1985 and 1995, data from 14 weather stations were used to create isohyetal maps via interpolation techniques in the Surfer program version 8 (ROSA et al., 2007).

Another study in Mato Grosso State, but covering only the Pantanal, mapped the distribution of rainfall using data from 5 weather stations covering the 30 years from 1977 to 2006, and isohyetal maps were elaborated via the Topo to Raster method, which uses the simple multi-grid method to minimize the equation for better resolutions (MARCUZZO et al., 2011b).

Using a GIS (Geographic Information System) for the spatial representation of climatic variables has been crucial as it represents an approximation to the reality of 
particular variables in areas of interest (Marcuzzo et al., 2011b). As rainfall is monitored at collection points which provide specific information, spatial interpolation methods are necessary to create maps (MELLO et al., 2005).

Geostatistics stand out among the interpolators and requires samples correlated in space, which differs from statistical techniques that do not consider the spatial dependency of collection points and use the average and standard deviation, which are based on the hypothesis that the sampled values have a normal distribution and that local variations are random (GOMES et al., 2002).

The geostatistical interpolator is considered to be better in comparison with the other interpolation methods. However, the best possible semivariogram must be modeled before interpolation (MELLO et al., 2005; RIBEIRO JUNIOR; DIGGLE, 2016).

The process of choosing the variographic methods and models that best represent the variable in question is the main stage in the geostatistical method. The statistical methods include: Ordinary least squares, Weighted least squares, Maximum likelihood, Restricted maximum likelihood, as well as various models available in computer programs for semivariogram adjustments, including: Spherical, Exponential, Gaussian, and Wave, among others (R CORE TEAM, 2015). After the choice of a mathematical model it is possible to carry out interpolation with a Kriging, which requires a spatial dependency between neighboring samples, represented by the semivariogram. Then it is possible to estimate values in other locations in the study area without sampling (CRESSIE, 1993).

Similarly to this study, in São Paulo State the spatial distribution of the 75 percentile from a ten-day rainfall was also evaluated, but only in the spring period, using data from 136 weather stations and creating isohyetal maps via geostatistical interpolation, enabling the authors to verify the spatial variability reflecting the behavior of atmospheric circulation in the State (GOMES et al., 2002).

\section{OBJECTIVE}

In this frame, the objective of this research is to adjust and choose semivariographic mathematical models for a spatial variability analysis of the 75 percentile of ten-day rainfall in Mato Grosso State, from October to March, to represent it via maps using Kriging techniques.

\section{MATERIAL AND METHODS}

\section{Rainfall data}

The daily rainfall data were obtained by 155 weather stations installed in and around Mato Grosso State (Figure 1) available at the National Water Agency - ANA internet portal (HIDROWEB, 2012), with historical records for at least 10 years. Data from October to March were chosen because these months involve the highest rainfall in this region. The 75 percentile was used because it increases the reliability degree of rainfall occurrence (HANN, 2002). 


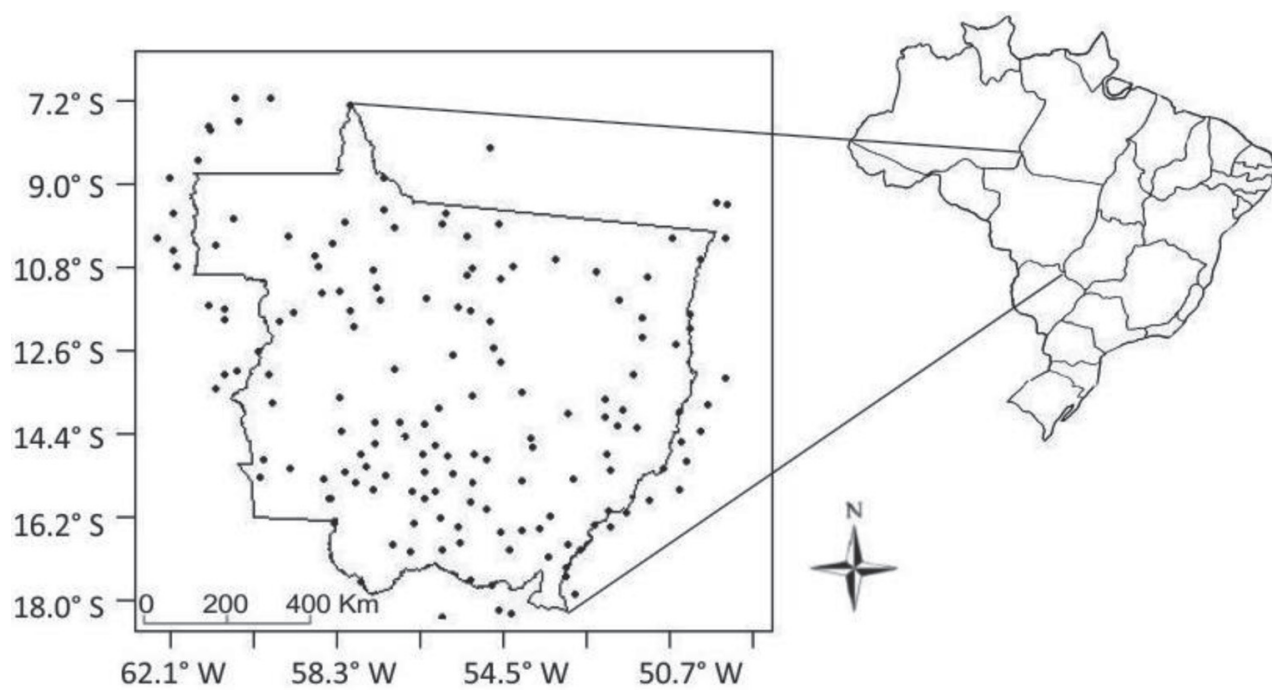

Figure 1 - Location of weather stations in Mato Grosso and neighbor States

\section{Geostatistics}

The Regionalized Variable Theory was developed by Matherson based on the observations from Krige and in his honor Matherson called his method "kriging" (geostatistical interpolation). A regionalized variable is a numerical function with spatial distribution, with variation from one location to another, apparently continuous; however these variations cannot be represented by a simple mathematical function (BURROUGH; MCDONNELL, 1998).

A variable dependent on geographical coordinates is considered as regionalized and can vary continuously in the geographical space. Each observed value $z\left(x_{i}\right)$ in locations $x_{i}, i=1,2, \ldots, \mathrm{n}$, wherein $x_{i}$ denotes the geographical coordinates in two dimensions. It is considered a realization of the random variables $z(x)$. The set of random variables constitutes a random function or stochastic process (McBratney \& Webster, 1986). Half of the expected variance between the pairs of points separated by a distance ' $h$ ' is defined as semivariance and is represented by the classical model (Eq. 1):

$$
\hat{\gamma}(h)=\frac{1}{2 N(h)} \sum_{i=1}^{N(h)}\left[z\left(x_{i}\right)-z\left(x_{i}+h\right)\right]^{2}
$$

where $\hat{\gamma}(h)$ is the estimated semivariance for each distance (lag) between pairs of points, $N(h)$ is the number of pairs of measured values $z\left(x_{i}\right), z\left(x_{i}+h\right)$, separated by distance $h$ (BURROUGH; MCDONNELL, 1998).

Using the adjusted semivariographic model, spatial patterns can be described and values predicted for non-sampled locations by Kriging, the best non-biased linear estimator, whose estimates are weighted by linear combinations of the existing data, with an average of null errors and minimum variance for the estimation errors. The 
Spherical (Eq. 2), Exponential (Eq. 3), and Gaussian (Eq. 4) models were thus adjusted to the experimental semivariograms, using the Least Squares method:

$$
\begin{gathered}
\gamma(h)=\left\{\begin{array}{l}
C_{0}+C_{1}\left[\frac{3 h}{2 a}-\frac{1}{2}\left(\frac{h}{a}\right)^{3}\right], 0<h<a \\
C_{0}+C_{1}, \quad h \geq a
\end{array}\right. \\
\gamma(h)=C_{0}+C_{1}\left\{1-\exp \left(-3 \frac{h}{a}\right)\right\} \\
\gamma(\mathrm{h})=\mathrm{C}_{0}+C_{1}\left\{1-\exp \left[-3\left(\frac{h}{a}\right)^{2}\right]\right\}
\end{gathered}
$$

where ' $C$ ' ' is the nugget effect, ' $C_{0}+C_{1}$ ' the sill, ' $a$ ' the range, and ' $h$ ' the distance.

To choose the mathematical model that best adjusts to the experimental semivariograms, the Spatial Dependence Degree Index (SDDI) and cross validation were used as criteria.

The SDDI was calculated by the ratio between the structural variance $\left(C_{1}\right)$ and the sill $\left(C_{0}+C_{1}\right)$, where for values below $25 \%$ the semivariogram is considered weak; for values between $25 \%$ and $75 \%$ it is considered moderate; and above $75 \%$ it is considered strong (MELLO, 2005).

The cross validation technique was used as a comparison criterion, consisting of the temporary removal of an observed value from the dataset and estimate it based on the others. This process is carried out for all the observed values. Subsequently, the standard deviation at the reduced errors was calculated $\left(S_{E R}\right)$ (Eq. 5) in accordance with Cressie (1993):

$$
S_{E R}=\sqrt{\frac{1}{n} \sum_{i-1}^{n}\left(\frac{z\left(x_{i 0}\right)-\hat{z}\left(x_{i 0}\right)}{\sigma_{i 0}}\right)^{2}}
$$

were $z\left(x_{i 0}\right)$ is the value observed at point $i_{0}, \hat{Z}\left(x_{i 0}\right)$ is the value estimated for point $i_{0}$, and $\sigma\left(x_{i 0}\right)$ is the standard deviation in Kriging at point $i_{0}$. The standard deviation of the reduced errors should be close to one.

After the choice of the best estimation model to verify the spatial dependency, the construction of the maps follows, using ordinary Kriging as an interpolator, which enables the visualization of spatial variability of rainfall.

The R program (R CORE TEAM, 2015) and geoR Geostatistical Analysis Package (RIBEIRO; DIGGLE, 2016) were used. 


\section{RESULTS AND DISCUSSION}

The highest rainfall in Mato Grosso State corresponds to the period between October and March, the so-called "Rainy season" (MARCUZZO et al., 2011a). In general, the $75 \%$ probability of higher rainfall occurrence was in the North of the State and over the ten-day periods the value of the 75 percentile of rainfall, increased from October to January, with a peak in average value of $57.45 \mathrm{~mm}$ occurring in the first ten days of January. As for the south of the State, the rainfall probability was lower, with the Pantanal as the biome with the lowest rainfall rates. The months with the highest rainfall probability are December, January, and February (Figure 2).

The main atmospheric mechanisms that act in the Brazil Central West region, and specifically in Mato Grosso State, are the Atlantic Polar Mass, with more frequency in the winter, and the Continental Equatorial Air Mass derived from the thermal effect and high humidity that occurs specially during the rainy period, displacing to the interior of the country in a NE to SW direction and causing rains (MARCUZZO et al., 2011a), which explains the higher rainfall volumes in this period.

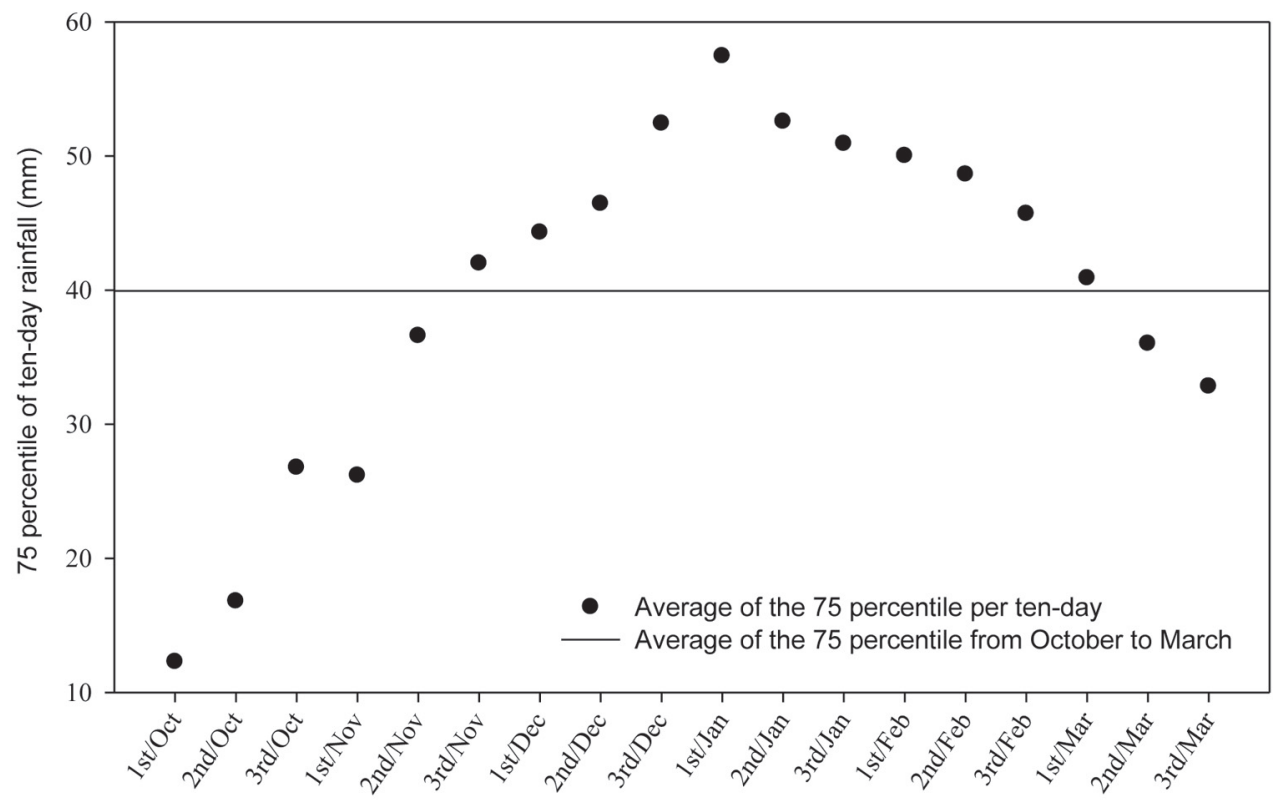

Ten-days/Month

\section{Figure 2 - Average of the 75 percentile of ten-day rainfall $(\mathrm{mm})$ from October to March in Mato Grosso State}

Classical statistics using average values give only an idea of the 75 percentile of rainfall for each ten-day period; that is, the average for each location, or in this case, an average for Mato Grosso State (Figure 2). It does not provide information on the spatial variability of the phenomenon. Hence the decision to represent the variable on maps. 
Since Geostatistics requires adjusting mathematical models and selecting the most adequate, or rather, that one with the best adjustments to the experimental semivariograms. As a key stage before elaborating the maps, the Spherical, Exponential, and Gaussian models were adjusted and tested. The nugget effect $\left(C_{0}\right)$, sill $\left(C_{0}+C_{1}\right)$, and range (a) parameters, as well as the values for standard deviation in the reduced errors $\left(\mathrm{S}_{\mathrm{ER}}\right)$ and spatial dependence degree index (SDDI), which are the criteria for selecting the best model, are shown in Table 1 below.

Table 1 - Nugget effect $\left(C_{0}\right)$, sill $\left(C_{o}+C_{1}\right)$, and range (a) parameters of the models from the Spherical, Exponential, and Gaussian semi-variograms, standard deviation in the reduced errors $\left(S_{E R}\right)$, and SDDI for the 75 percentile of ten-day rainfall from October to March in Mato Grosso State

\begin{tabular}{|c|c|c|c|c|c|c|c|}
\hline Month & Ten-days & Model & $C_{o}$ & $C_{o}+C_{1}$ & $a(m)$ & $S_{E R}$ & SDDI (\%) \\
\hline \multirow{9}{*}{$\begin{array}{l}\text { 㞻 } \\
\text { ○ } \\
\text { 응 }\end{array}$} & $1 \mathrm{st}$ & Spherical & 17.75 & 72.40 & 1097316 & 1.100 & 75.48 \\
\hline & & Exponential & 18.23 & 109.59 & 1090000 & 1.077 & 83.37 \\
\hline & & Gaussian & 22.00 & 72.36 & 516575 & 1.205 & 69.60 \\
\hline & 2nd & Spherical & 25.88 & 83.38 & 1080000 & 1.084 & 68.95 \\
\hline & & Exponential & 25.34 & 125.09 & 1080000 & 1.079 & 79.74 \\
\hline & & Gaussian & 29.00 & 85.59 & 535209 & 1.150 & 66.12 \\
\hline & $3 r d$ & Spherical & 32.92 & 124.62 & 939999 & 1.068 & 73.58 \\
\hline & & Exponential & 34.55 & 186.33 & 940000 & 1.042 & 81.46 \\
\hline & & Gaussian & 35.00 & 127.55 & 458513 & 1.230 & 72.56 \\
\hline \multirow{9}{*}{ 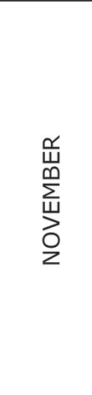 } & $1 \mathrm{st}$ & Spherical & 45.78 & 95.30 & 1100000 & 1.031 & 51.96 \\
\hline & & Exponential & 45.32 & 133.55 & 1140000 & 1.028 & 66.07 \\
\hline & & Gaussian & 49.00 & 103.17 & 632234 & 1.079 & 52.51 \\
\hline & 2 nd & Spherical & 57.03 & 108.54 & 600000 & 1.037 & 47.46 \\
\hline & & Exponential & 62.72 & 130.44 & 600000 & 1.004 & 51.91 \\
\hline & & Gaussian & 62.00 & 114.39 & 401186 & 1.075 & 45.80 \\
\hline & 3 rd & Spherical & 62.09 & 145.89 & 760000 & 1.009 & 57.44 \\
\hline & & Exponential & 63.20 & 167.41 & 500022 & 0.985 & 62.25 \\
\hline & & Gaussian & 63.00 & 146.03 & 351908 & 1.105 & 56.86 \\
\hline \multirow{9}{*}{$\begin{array}{l}\text { 岀 } \\
\sum_{\text {岂 }}^{\text {岁 }}\end{array}$} & $1 \mathrm{st}$ & Spherical & 68.24 & 175.02 & 950000 & 1.039 & 61.01 \\
\hline & & Exponential & 70.94 & 246.32 & 970000 & 1.021 & 71.20 \\
\hline & & Gaussian & 80.00 & 185.47 & 540103 & 1.051 & 56.87 \\
\hline & $2 n d$ & Spherical & 96.64 & 269.63 & 1063621 & 1.061 & 64.16 \\
\hline & & Exponential & 96.70 & 367.68 & 950000 & 1.052 & 73.70 \\
\hline & & Gaussian & 119.00 & 272.26 & 529636 & 1.052 & 56.29 \\
\hline & $3 \mathrm{rd}$ & Spherical & 81.09 & 493.67 & 1388271 & 1.144 & 83.57 \\
\hline & & Exponential & 72.19 & 810.01 & 1390000 & 1.169 & 91.09 \\
\hline & & Gaussian & 111.00 & 469.35 & 599539 & 1.175 & 76.35 \\
\hline
\end{tabular}




\begin{tabular}{|c|c|c|c|c|c|c|c|}
\hline \multirow{9}{*}{ 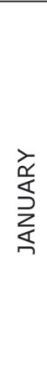 } & 1st & Spherical & 82.44 & 353.15 & 911371 & 1.064 & 76.66 \\
\hline & & Exponential & 93.54 & 551.44 & 990000 & 1.017 & 83.04 \\
\hline & & Gaussian & 112.00 & 358.21 & 453480 & 1.095 & 68.73 \\
\hline & 2nd & Spherical & 74.00 & 163.17 & 477683 & 1.011 & 54.65 \\
\hline & & Exponential & 73.00 & 175.95 & 241907 & 0.978 & 58.51 \\
\hline & & Gaussian & 76.00 & 159.21 & 187879 & 1.071 & 52.27 \\
\hline & 3rd & Spherical & 69.00 & 130.62 & 300000 & 1.089 & 47.18 \\
\hline & & Exponential & 65.00 & 143.29 & 181106 & 1.061 & 54.64 \\
\hline & & Gaussian & 67.00 & 132.16 & 151616 & 1.147 & 49.30 \\
\hline \multirow{9}{*}{ 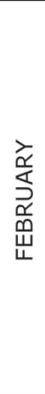 } & $1 s t$ & Spherical & 60.00 & 217.81 & 482992 & 1.175 & 72.45 \\
\hline & & Exponential & 61.00 & 240.35 & 240824 & 1.098 & 74.62 \\
\hline & & Gaussian & 64.00 & 204.61 & 175582 & 1.333 & 68.72 \\
\hline & 2nd & Spherical & 79.66 & 165.62 & 373984 & 1.102 & 51.90 \\
\hline & & Exponential & 80.00 & 166.34 & 130785 & 1.039 & 51.91 \\
\hline & & Gaussian & 86.00 & 165.68 & 177591 & 1.146 & 48.09 \\
\hline & 3rd & Spherical & 41.00 & 109.49 & 525629 & 1.123 & 62.55 \\
\hline & & Exponential & 42.00 & 144.15 & 438740 & 1.090 & 70.86 \\
\hline & & Gaussian & 43.00 & 107.97 & 235603 & 1.244 & 60.18 \\
\hline \multirow{9}{*}{ 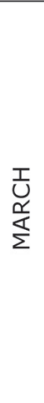 } & 1st & Spherical & 73.00 & 237.29 & 522831 & 1.083 & 69.24 \\
\hline & & Exponential & 75.50 & 311.61 & 412095 & 1.051 & 75.77 \\
\hline & & Gaussian & 76.00 & 228.38 & 215931 & 1.245 & 66.72 \\
\hline & 2nd & Spherical & 60.00 & 151.73 & 419139 & 1.083 & 60.46 \\
\hline & & Exponential & 66.00 & 170.78 & 470001 & 1.022 & 61.35 \\
\hline & & Gaussian & 59.00 & 148.08 & 164678 & 1.186 & 60.16 \\
\hline & $3 r d$ & Spherical & 68.91 & 127.94 & 300007 & 1.241 & 46.14 \\
\hline & & Exponential & 67.00 & 148.88 & 300004 & 1.241 & 55.00 \\
\hline & & Gaussian & 66.00 & 127.71 & 129999 & 1.241 & 48.32 \\
\hline
\end{tabular}

To choose a variogram model, a visual analysis of the behavior from the semivariograms is not enough on its own since this is a subjective analysis. Thus, the Standard Deviation in Reduced Errors $\left(S_{E R}\right)$ obtained via cross validation and the SDDI were used as a form of more objective evaluation. The $S_{R E}$ results for the Exponential Model were close to "one" and can thus be considered as accurate and precise for all of the semivariograms analyzed (Cressie, 1993). Using the spatial dependency criterion, for values below $25 \%$ the SDDI is considered as weak, between $25 \%$ and $75 \%$ moderate, and above $75 \%$ strong. From the semivariograms adjusted by the Exponential Model, $67 \%$ presented moderate and 33\% presented strong spatial dependency.

For these two criteria the superiority of the Exponential Model in relation to the other models is evident. It performed better than the Spherical and Gaussian models.

Figures 3 and 4 present the semivariograms chosen and adjusted by the Exponential Model of the 75 percentile of rainfall for each ten days between October and March. 
In general, the semivariograms presented rising semivariances until a certain distance " $a$ " when they stabilize, coinciding with the sill and indicating that a stationary state is guaranteed and the parameters generated can be used to estimate rainfall values in non-collected locations. However, models such as the Exponential one, among others, only reach the sill in an asymptotic way (CRESSIE, 1993).

The behavior of the range is associated with the existence of a structure with spatial dependence; that is: it is a distance at which there is a spatial correlation between the locations of the variable in question. As the model chosen was exponential, the range related to this model varied from 130 to $1390 \mathrm{~km}$ in the second ten-day period of February and in the third ten-day period of December, respectively. These values represent the extension of the spatial dependence structure of the 75 percentile of rainfall in and around Mato Grosso State, with December practically covering the entire State.

The nugget effect, sill, and range related to the chosen semivariograms were used to carry out the Kriging and generate the maps.
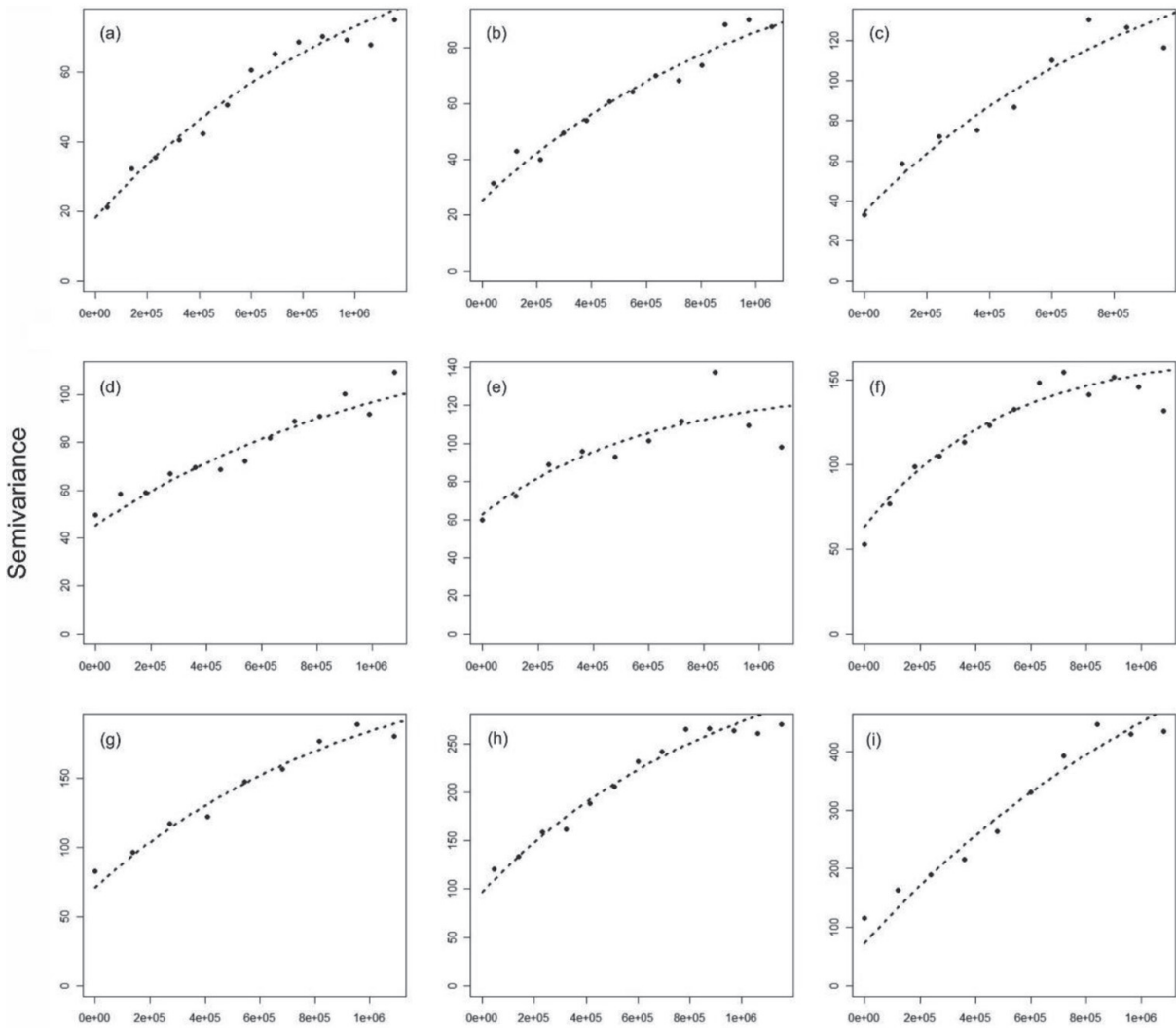

Distance $(m)$

Figure 3 - Experimental semivariograms related to the 75 percentile of ten-day rainfall in Mato Grosso State, adjusted by the exponential model, for the $1^{\text {st }}, 2^{\text {nd }}$, and $3^{\text {rd }}$ ten days of $\operatorname{October}(a, b, c)$, November $(d, e, f)$, and December $(g, h, i)$, respectively 

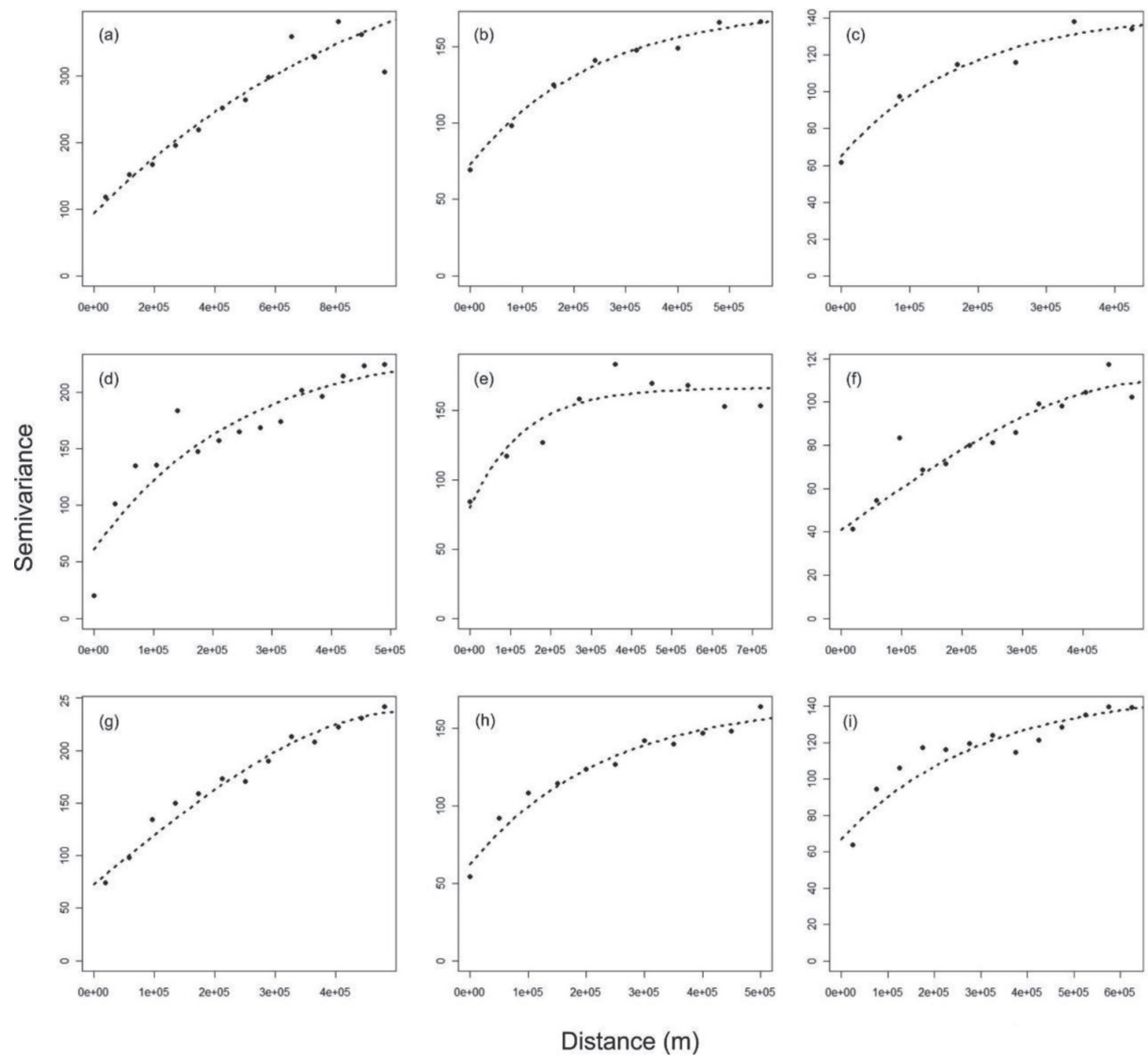

Figure 4 - Experimental semivariograms related to the 75 percentile of ten-day rainfall in Mato Grosso State, adjusted by the exponential model, for the $1^{\text {st }}, 2^{\text {nd }}$, and $3^{\text {rd }}$ ten days of January $(a, b, c)$, February $(d, e, f)$ and March $(g, h, i)$, respectively

Results from other Brazilian States support the choice for the exponential model in this study. These include the case study of rainfall in Minas Gerais State, where variogram models were adjusted and the Exponential Model chosen was the best in performance, compared to the others (MELLO et al., 2008).

For intensive rainfall in São Paulo State, two different interpolators were evaluated, with the geostatistical method being superior to the other method, and the Exponential Model was adjusted using the trial and error method, generating precise maps by Kriging. The authors concluded that the results were precise and that the method should be applied always when possible (MELLO et al., 2003).

Another study on the spatial behavior of rainfall in São Paulo State using annual precipitation data from 379 weather stations compared different semivariogram adjustment models and the Exponential one was superior to the other ones (CARVALHO et al., 2004). 
To estimate and analyze the standard behavior of the 75 percentile of ten-day rainfall in São Paulo State, mathematical models were also compared and the best performance presented the Exponential Model followed by the Spherical one (GOMES et al., 2002).

After selecting the mathematical model that best adjusts to the experimental semivariograms, the next geostatistical stage was the interpolation by Ordinary Kriging, generating maps on the probability of rainfall occurrence.

The distribution of the values of the 75 percentile of rainfall, modeled and mapped for each ten days from October to March correspond to the rain period in Mato Grosso State, presenting a spatial variation from one extreme of the State to the other (Figures 5 and 6).
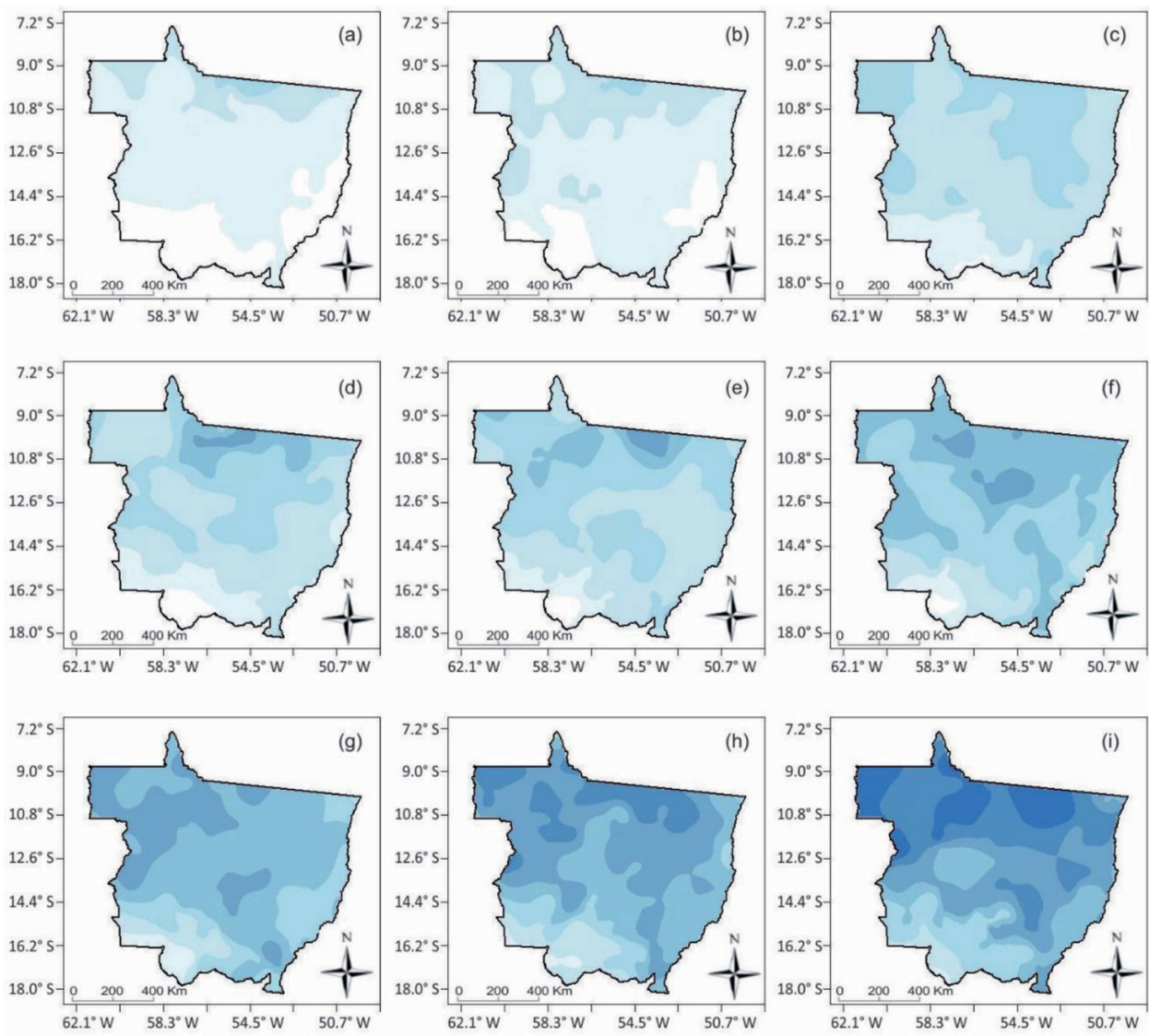

Figure 5 - Maps of spatial variability of the 75 percentile of ten-day rainfall $(\mathrm{mm})$ in Mato Grosso State, involving the $1^{\text {st }}(\mathrm{a}), 2^{\text {nd }}(\mathrm{b})$, and $3^{\text {rd }}$ (c) ten days of October, $1^{\text {st }}(d), 2^{\text {nd }}(e)$, and $3^{\text {rd }}(f)$ of November, and $1^{\text {st }}(g), 2^{\text {nd }}$ (h), and $3^{\text {rd }}(i)$ of December 

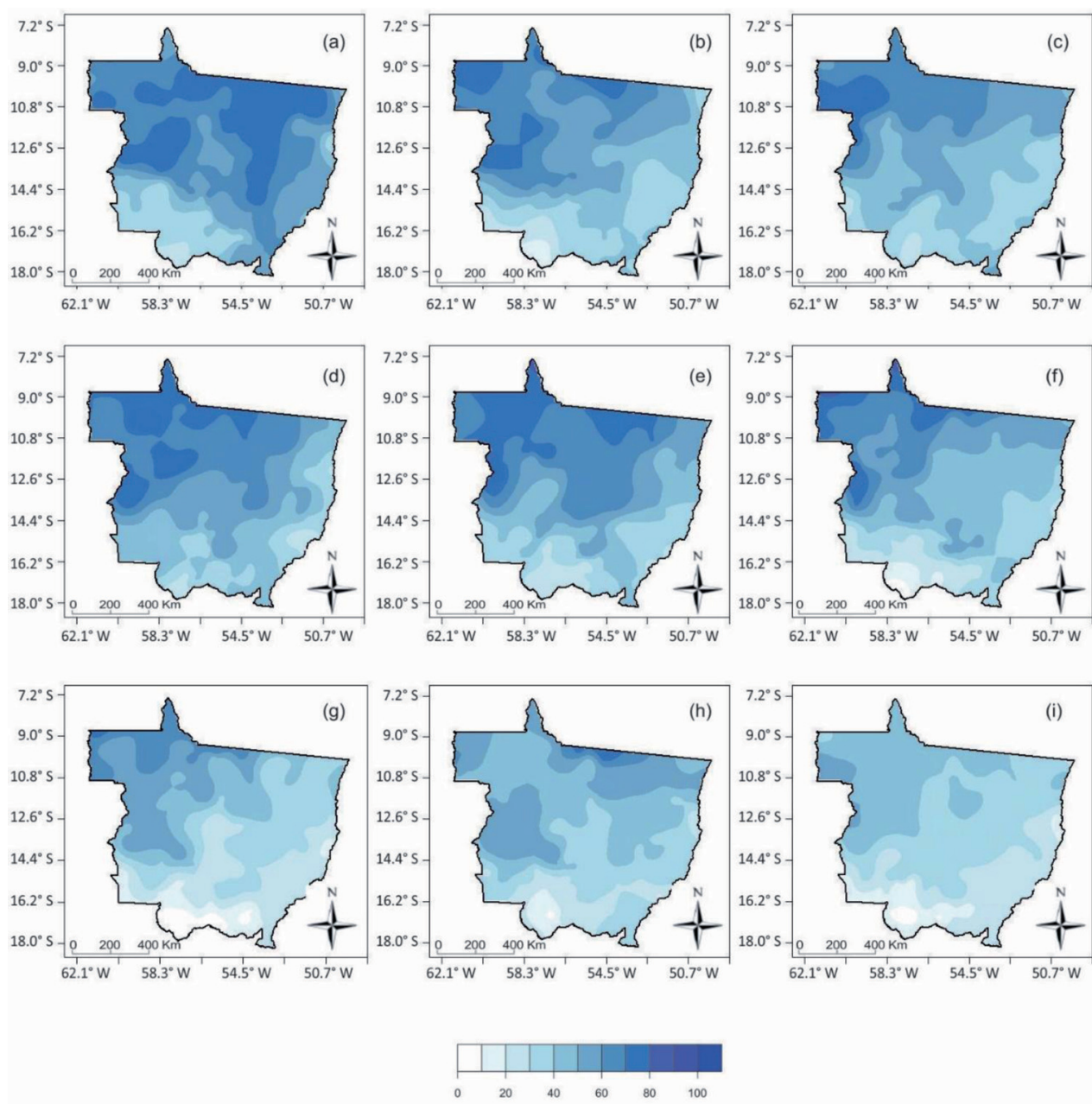

Figure 6 - Maps of spatial variability of the 75 percentile of ten-day rainfall $(\mathrm{mm})$ in Mato Grosso State, involving the $1^{\text {st }}(\mathrm{a}), 2^{\text {nd }}(\mathrm{b})$, and $3^{\text {rd }}$ (c) ten days of January, $1^{\text {st }}(d), 2^{\text {nd }}(e)$, and $3^{\text {rd }}(f)$ of February, and $1^{\text {st }}(g)$, $2^{\text {nd }}(h)$, and $3^{\text {rd }}(i)$ of March

One observes that the values of the 75 percentile of rainfall varied throughout Mato Grosso State, which includes three great physiographical units: the Amazon, Pantanal, and Cerrado biomes. The highest rainfall probability values were placed at the extreme NE and north of the territory, in the Amazon biome, which could surpass a probability of $100 \mathrm{~mm}$. There was a north-south decrease with the lowest values being in the extreme SE and south, corresponding to the Pantanal biome, especially in October.

The 75 percentile of ten-day rainfall in the $1^{\text {st }}$ and $2^{\text {nd }}$ ten days of October showed a similar behavior, with higher probabilities of rain in the north and lower 
probabilities in the south, but with a lower average (Figure 1) and the probability of increasing over the ten-day periods until the $1^{\text {st }}$ ten days of January and decreasing again until March.

Mato Grosso State presents physical peculiarities such as a terrain and a vegetation that directly influence the spatial variability of precipitation, as well as the geographical positioning, since Mato Grosso is under the influence of three climatic units of the region: Wet Equatorial Continental Climate, Wet Sub-Equatorial Continental Climate, and alternating Wet and Dry Tropical Continental Climate (COUTINHO, 2005). The influence of the Parecis and Guimarães uplands, located in the mid-west and mideast, respectively, is perceived in the spatial distribution of rainfall in Mato Grosso. Relief-induced rains can potentially occur in these regions making them more rainy if compared to localities at the same latitudes without the influence of altitude.

The study on rainfall distribution in Mato Grosso State by Marcuzzo et al. (2011a) presented a big variation in precipitation rates, where the localities with the highest rainfall values were also identified in the extreme NE and north and the localities in the south of the State had the lowest rainfall amounts.

Rosa et al. (2007), in an analysis of the spatial distribution and annual rainfall variability in the Central-West portion of Mato Grosso State, observed that the municipalities with the highest recorded rainfalls were Nobres and Diamantino, the latter being approximately $10 \mathrm{~km}$ from the source of the Paraguay river in the municipality of Alto Paraguay, a coherent result with the maps generated in this study. These authors also observed that the rains were irregular, thus supporting this result.

\section{CONCLUSIONS}

It is concluded that from the semivariographic models analyzed, the one that adjusted best to the experimental semivariograms for the 75 percentile of ten-day rainfall in Mato Grosso, from October to March, was the Exponential one. It was chosen by cross validation and the SDDI to describe the spatial dependence structure of the precipitation.

The maps allowed to identify that the behavior of the spatial distribution of the 75 percentile of rainfall was variable with higher values in the north and NE and lower ones in the south and SE.

Therefore, the study of the spatial rainfall variability in Mato Grosso State enabled the generation of maps to analyze the behavior of the rainfall probability occurrence, at a level of $75 \%$, thus providing crucial information for agricultural planning and decision making. Geostatistics was therefore a fundamental tool for this study, permitting a semivariographic analysis resulting in parameters used in the Kriging stage and the generation of maps.

\section{ACKNOWLEDGEMENTS}

The authors acknowledge the National Water Agency (ANA) for providing the data on the website (<http://hidroweb.ana.gov.br>) used in this paper. 


\section{REFERENCES}

BURRough, P. A.; MCDONNELL, R. A. Principles of geographical information systems. Oxford: Oxford University Press, 1998. 333p.

CARVALHO, J. R. P. de; VIEIRA, S. R.; VENDRUSCULO, L. G. Uso da técnica de mínimos quadrados ponderados para ajuste de modelos as semivariograma. Campinas: Embrapa Informática Agropecuária, 2004.

COUTINHO, A. C. Dinâmica das queimadas no Estado do Mato Grosso e suas relações com as atividades antrópicas e a economia local. 2005. 308f. Tese (Doutorado em Ciência Ambiental) - Procam, Universidade de São Paulo, USP, 2005.

CRESSIE, N. Statistics for spatial data. New York: Wiley. 1993.

GOMES, B. M.; CRUZ, R. L. Comportamento especial dos percentis 75 da precipitação decendial para o Estado de São Paulo, na primavera. Irriga, v. 7, n. 2, p. 142-153, 2002.

HANN, C. T. Statistical Methods in Hydrology. 2. ed. Ames: The Iowa State University Press, 2002. 377p.

HIDROWEB. Sistema de Informações Hidrológicas. Available at: <http:// hidroweb.ana.gov.br>. Access in June 25 2012.

MARCUZZO, F. F. N.; MELO, D. C. R.; ROCHA, H. M. Distribuição Espaço-temporal e Sazonalidade das Chuvas no Estado de Mato Grosso. Revista Brasileira de Recursos Hídricos, v. 16, n. 4, p. 157-167, 2011 a.

MARCUZZO, F. F. N.; ROCHA, H. M.; MELO, D. C. R. Mapeamento da precipitação pluviométrica no Bioma Pantanal do Estado do Mato Grosso. Geoambiente On-line, n. 16, p. 66-84, 2011b.

McBRATNEY, A. G.; WEBSTER, A. G. Choosing functions for semivariograms and fitting them to sampling estimates. Journal of Soil Science, v. 37, p. 617-639, 1986.

MELLO, C. R. de; LIMA, J. M.; SILVA, A. M.; MELLO, J. M.; OLIVEIRA, M. S. Krigagem e inverso do quadrado da distância para interpolação dos parâmetros da equação de chuvas intensas. Revista Brasileira de Ciência do Solo, v. 27, n. 5, p. 925-933, 2003.

MELLO, C. R. DE; VIOLA, M. R.; MELLO, J. M.; SILVA, A. M. Continuidade espacial de chuvas intensas no Estado de Minas Gerais. Ciência e Agrotecnologia, v.32, n.2, p. 532-539, 2008.

MELLO, J. M.; BATISTA, J. L. F.; RIBEIRO JUNIOR, P. J.; OLIVEIRA, M. S. Ajuste e seleção de modelos espaciais de semivariograma visando a estimativa volumétrica de Eucaliptus grandis. Scientia Forestalis, v. 1, n. 1, p. 25-37, 2005.

RIBEIRO, P. J.; DIGGLE, P. J. (2016). geoR: Analysis of Geostatistical Data. R package version 1.7-5.2. https://CRAN.R-project.org/package $=$ geoR

R Core Team (2015). R: A language and environment for statistical computing. R Foundation for Statistical computing, Vienna, Austria. URL https://www.R-project.org. ROSA, D. B.; SOUSA, R. R.; NASCIMENTO, L. A.; TOLEDO, L. G.; TOPANOTTI, D. Q.; NASCIMENTO, J. A. A distribuição especial das chuvas na porção Centro-Oeste do Estado de Mato Grosso-Brasil. Revista Eletrônica da Associação dos Geógrafos Brasileiros, Seção Três Lagoas, v. 1, n. 5, 2007. 